\title{
Sistem Pengukuran Kinerja Sektor Publik: \\ Telaah Kritis Terhadap Kebutuhan Pengukuran \\ Kinerja Pemerintah Daerah
}

\author{
Mardiasmo
}

At the moment the interest in the use of performance measurement is at its greatest and there has been a number of studies that focuses on local government. Performance mesurement is an important tool for evaluating value for money in the public sector. Performance measures gives life to the vision, mission, and strategy by providing a focus that let each employee know how they have contribute to the success of an organization and stakeholder's measurable expectations. This statement is an answer for the question on why establish an integrated performance measurement system and establish accountability of performance measure. Accountability has to be established first through "accountability environment" then accountability framework. The environment integrates accountability into the individual, team, and organizational performance system whereas the framework ensures the execution and fulfillment of the accountability obligations.

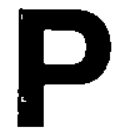

eran pemerintah daerah sangat menyentuh kehidupan masyarakat, bahkan peran pemerintah tersebut sering menjadi pusat layanan bagi berbagai keperluan masyarakat. Pelayanan jasa yang diselenggarakan oleh pemerintah daerah mempengaruhi kualitas hidup masyarakat dan hasil yang dicapai atas penyelenggaraan pelayanan tersebut menunjukkan tingkat peradaban masyarakatnya (Donnelly, 1998). Masyarakat terus berkembang dengan segenap tuntutannya, demikian juga pemerintah daerah. Hal ini berimplikasi pada kompleksitas layanan jasa yang harus disediakan oleh pe- merintah daerah. Kompleksitas layanan yang semakin tinggi membawa pada suatu implikasi lanjutan terhadap tuntutan peningkatan kinerja dan akuntabilitas kinerja pemerintah daerah.

Tuntutan yang tinggi terhadap kinerja dan akuntabilitas kinerja pemerintah daerah ini berujung pada kebutuhan pengukuran kinerja pemerintah daerah. Pengukuran kinerja pemerintah daerah mempunyai banyak tujuan. Tujuan tersebut paling tidak untuk meningkatkan kinerja dan meningkatkan akuntabilitas pemerintah daerah (Audit Comission UK., 1999). Untuk itu, pemerintah daerah dituntut untuk mampu 
membangun ukuran kinerja yang baik. Ukuran kinerja yang disusun tidak dapat hanya dengan menggunakan satu ukuran. Oleh karena itu, perlu ukuran yang berbeda untuk tujuan yang berbeda. Hal inilah yang kadang-kadang membuat konflik. Ukuran kinerja mempengaruhi ketergantungan antàr unit kerja yang ada dalam satu unit kerja (Abernethy, 2001).

Untuk menghindari adanya konflik seperti di atas maka perlu dikembangkan ukuran kinerja secara integral dalam suatu sistem pengukuran kinerja (SPK). Disain sistem pengukuran kinerja yang dikembangkan secara terus menerus dan didukung kompetensi penyusunnya dapat meminimalisasi perilaku oportunistik (Abernethy, 2001). Dengan adanya sistem ini maka tuntutan era transparansi yang saat ini sedang berlangsung pada sektor publik di segenap bidang diharapkan dapat didekati. $\mathrm{Hal}$ ini juga menjadi pendorong terhadap tuntutan kebutuhan transparansi dalam pengukuran kinerja pemerintah daerah terhadap pengelolaan sumber daya dan segenap aktivitasnya sebagai wujud stewardship dan accountability pada publik.

Organisasi sektor publik memiliki ciri yang berbeda dengan organisasi swasta yang lebih berorientasi pada laba. Lebih jauh, perbedaan kedua jenis organisasi tersebut sebagian terletak pada masalah output, outcomes, dan tujuan utama organisasi. Perbedaan tersebut membuat sistem akuntabilitas pemerintah menjadi sulit untuk diukur. Selain itu, penyusunan dan penerapan indikator yang baik juga masih sulit dirumuskan. Sebagian besar entitas pemerintah berupa entitas layanan jasa (public service) yang memiliki tujuan utama pada penyediaan jasa layanan pada masyarakat dan tidak semata-mata mencari keuntungan (laba). Oleh karena itu, output public senvice sulit untuk dilakukan pengukuran baik secara kuantitatif maupun secara kualitatif.
Pada sektor komersial secara umum terdapat kecenderungan menggunakan Laporan Keuangan sebagai suatu ukuran kinerja. Laporan Laba/Rugi merupakan bagian dari laporan keuangan yang menjadi ukuran puncak untuk mengukur kinerja pada sektor komersial apakah berhasil atau tidak. Pada sektor publik, tujuan tidak dapat diukur hanya dengan menggunakan indikator laba semata, oleh karena itu memerlukan indikator lain yang sesuai dengan karakteristik organisasi sektor publik tersebut.

\section{Kebutuhan Pengukuran Kinerja}

Berbagai gejolak yang terjadi pada saat ini sangat berkaitan dengan ketidakpuasan masyarakat terhadap penyelenggaraan administrasi publik. Di berbagai belahan bumi, hal tersebut dipicu oleh rasa ketidakpuasan rakyat atas pengelolaan kekayaan negara oleh para penguasa yang diberi amanah oleh rakyatnya. Selain itu, gelombang pembaharuan pemerintah (reinventing govemment) tahun 1980 hingga 1990-an menempatkan pengukuran kinerja pada pemerintah menjadi sesuatu yang diterima umum (David, 2000).

Hal tersebut juga terjadi di Indonesia, berbagai komponen masyarakat secara bergantian dan bersama-sama mencoba menyampaikan aspirasinya baik dalam bentuk demonstrasi, memberikan laporan terhadap penyimpangan yang terjadi, melakukan mogok kerja, ataupun melaksanakan mogok makan dalam rangka memperjuangkan hak-hak mereka serta mendorong adanya perubahan yang bermuara pada perubahan sistem pengelolaan dana publik (public money) menuju kondisi yang lebih baik. Dengan adanya tuntutan baik yang bersifat global maupun nasional tersebut, pemerintah dituntut mampu merespon aspirasi mereka secara tepat. 
Pemerintah dan wakil rakyat kita telah menanggapi hal tersebut di atas dengan mengelaborasi pada tataran hukum berupa Tap MPR No.XI/MPR/1999 dan UU No. 28 Tahun 1999. Keduanya tentang Penyelenggaraan Negara yang Bersih dan Bebas Korupsi, Kolusi, dan Nepotisme. Kedua regulasi tersebut menegaskan tekad pemerintah untuk bersungguh-sungguh mewujudkan penyelenggaraan pemerintahan negara dan pembangunan yang didasarkan pada prinsip-prinsip good governance.

Sebagai tindak lanjut dari kedua bentuk hukum di atas, pemerintah telah menerbitkan Inpres No. 7 Tahun 1999 tentang Akuntabilitas Kinerja Instansi Pemerintah. Sesuai dengan inpres tersebut maka Lembaga Adiministrasi Negara (LAN) telah menerbitkan Buku Pedoman Penyusunan Pelaporan Akuntabilitas Kinerja Instansi Pemerintah. Hal ini dimaksudkan sebagai upaya terobosan dalam pembangunan sistem administrasi negara modern yang andal, demokratik, profesional, efisien, efektif, berkeadilan, bersih, terbuka, partisipatif, dan tanggap terhadap aspirasi masyarakat. Selain itu, dengan adanya pedoman tersebut diharapkan dapat memantapkan manajemen pemerintah daerah dan pembangunan yang accountable (LAN, 2000).

Government Accounting Standards Board (GASB) (1999) mensyaratkan pada entitas pemerintah untuk melakukan pengukuran terhadap apa yang mereka capai dengan pembelanjaan dari setiap rupiah yang dikeluarkan. Kebutuhan pengukuran kinerja juga didorong oleh beberapa alasan lainya antara lain perubahan sifat kerja, peningkatan persáingan, inisiatif peningkatan performance tertentu, penghargaan atas kualitas baik nasional maupun internasional (awarding), perubahan peran organisasi, perubahan permintaan di luar organisasi, dan kekuatan peran teknologi informasi (Andy, 1999).
Selain itu, tahun 1990-an pernah dilakukan usaha untuk melakukan formulasi indikator bagi pemerintah daerah yang dilaksanakan oleh Menteri Dalam Negeri (Kerjasama dengan Universitas Gadjah Mada) dan LAN. Namun demikian, ukuran yang disusun tersebut untuk menilai kesiapan pemerintah daerah dalam menghadapi dan melaksanakan otonomi daerah dan bukan untuk mengukur kinerja pemerintah daerah dalam mencapai visi, misi, dan tujuan utamanya.

Aturan baru yang berkaitan dengan masalah pengukuran kinerja antara lain Undang-undang (UU) No. 22 tahun 1999, Undang-undang No. 25 tahun 1999, Peraturan Permerintah (PP) No. 105 tahun 2000, dan Peraturan Pemerintah (PP) No. 108 tahun 2000. P.P No. 108 tahun 2000 mengharuskan Kepala Daerah bertanggung-jawab terhadap laporan pertanggungjawaban yang terdiri dari Laporan APBD, Nota Perhitungan APBD, Aliran Kas, dan Neraca yang didasarkan pada pengukuran kinerja yang berbasis rencana strategik. PP No.105 tahun 2000 menggunakan 4 proksi sebagai atat pengukuran kinerja pemerintah daerah yaitu standar pelayanan, standar analisa belanja, kriteria kinerja, dan standar biaya. Pada dataran normatif masih banyak ditemui kesulitan yang disebabkan karena pedoman teknis yang belum ada.

Dengan memahami kebutuhan terhadap sistem pengukuran kinerja seperti diuraikan di atas maka pemahaman tersebut akan membantu entitas sektor publik dalam memahami arti penting pengukuran kinerja yang pada gilirannya nanti akan mampu menyusun sistem bagi pengukuran kinerjanya.

\section{Pentingnya Pengukuran Kinerjà}

Organisasi dengan segenap kompleksitasnya umumnya berupaya dengan 
keras untuk menyelaraskan (alignment) berbagai aspek yang terkait dalam penyelenggaraan kegiatan organisasinya. Aspek-aspek tersebut umumnya berupa keuntungan (profit), pertumbuhan (growth), dan pengendalian (contro).

Pada organisasi yang berorientasi laba tentunya berupaya untuk mencari laba sebanyak-banyaknya. Pada sektor publik hal ini menjadi berbeda, karena tidak semuanya berorientasi semata-mata pada laba tetapi juga pada pelayanan. Selain itu, pada sektor komersial dan sektor publik juga didorong oleh tuntutan terhadap pertumbuhan perusahaan atau entitas (growth) dalam rangka merespon tuntutan kepentingan pemegang saham atau yang memberi amanah. Peningkatan pertumbuhan dan upaya memperbesar profit tentunya harus diikuti dengan adanya pengendalian .

Upaya untuk meningkatkan pertumbuhan dan profit jika tidak diselaraskan dengan pengendalian akan membahayakan bagi organisasi. Hal ini terjadi karena karyawan hanya akan berorientasi pada pertumbuhan dan laba, sementara mereka kurang atau tidak memperhatikan aspek-aspek seperti kepuasan karyawan itu sendiri terlebih lagi kepuasan konsumen. Disinilah letak pentingnya pengendalian yang diwujudkan dalam bentuk pengukuran kinerja baik pada sektor komersial maupun pada sektor publik.

Selain itu, pengukuran kinerja juga akan banyak memberikan manfaat bagi organisasi seperti; peningkatan kualitas jasa dan produk, memastikan akuntabilitas dan pengendalian, peningkatan kualitas praktik manajemen, formulasi kebijakan, perencanaan dan penganggaran, meyakinkan ekuitas dan pada distribusi dan kemampuan akses atas jasa. Pengukuran dan evaluasi kinerja merupakan sentral pengendalian dalam organisasi dan sangat berarti untuk menjawab pertanyaan seperti apa yang sedang terjadi, mengapa hal itu terjadi, apakah hal tersebut berlanjut, dan apa yang seharusnya dilakukan untuk itu (Shaw, 1999). Sistem pengukuran kinerja yang baik diperlukan untuk memastikan bahwa keseluruhan tujuan atas berdirinya suatu entitas dapat diawasi dan dikendalikan. Pengukuran juga menjadi kata kunci padà paradigma New Public Management (Alexander, 1999). Bahkan Audit Comission Pemerintah Inggris (1999) menyatakan sistem pengukuran kinerja sebagai suatu alat untuk melakukan modernisasi pemerintah.

Pentingnya pengukuran kinerja sebagai suatu praktik manajemen yang esensial ditekankan oleh GASB, yang menghasilkan serangkaian kewajiban laporan Service Efforts and Accomplishments (SEA) (Epstein 1992). Pentingnya pengukuran kinerja juga diakui oleh ICMA (Intemational City Management Association), yang membentuk sebuah Konsorsium Pengukuran Kinerja Komparatif dari 44 kota dan kabupaten untuk berkolaborasi dalam pengembangan sistem pengukuran dan menentukan yang terbaik. Pada jenjang pemerintah federal (US) sudah ada pengembangan yang penting, misalnya, Aturan Hasil dan Kinerja Pemerintah tahun 1993. Selain itu, beberapa negara bagian (US) juga sudah mengembangkan sistem pengukuran kinerja (Broom, 1995).

Informasi yang dihasilkan dari pengukuran kinerja dapat digunakan untuk perencanaan (pemilihan aiternatif strategi, pemilihan prioritas, perubahan arah kebijakan), penganggaran (sebagai rujukan terhadap penggunaan sumber daya, pengembangan biaya pencapaian target), implementasi (hasil aktual diperiksa terhadap anggaran dan tujuan, pedoman tindakan koreksi), dan evaluasi (membantu menunjukkan efektivitas program, pengujian dengan cara lain agar sesuai dengan tujuan, membantu menunjukkan cara yang terbaik 
untuk implementasi program) (James, 1997). Pengukuran kinerja telah mengalami perubahan dalam banyak dimensi ukuran kinerja yang digunakan. Untuk itu perlu kiranya dipahami perkembangan ukuran kinerja yang terjadi saat ini.

\section{Perkembangan Paradigma Ukuran dan Sistem Pengukuran Kinerja}

Paradigma ukuran kinerja dan sistem pengukuran kinerja mengalami evolusi dalam tiga arah (Geertz, 1993). Pertama, periuasan wilayah penggunaan. Banyak jenjang pemerintahan dan banyak bidang dari aktivitas yang dicakup oleh pengukuran kinerja. Lingkup jangkauan aktivitas dari daerah ke pemerintah pusat. Lingkup aktivitas yang dicakup meliputi teritorial dan fungsionalitas desentralisasi organisasi. Pada saat yang sama terdapat berbagai jenis layanan yang menggunakan pengukuran kinerja. Terdapat evolusi dari pengukuran yang tampak (tangible) atas layanan jasa dan produksi pemerintah ke dalam bentuk yang lebih tidak tampak (intangible).

Kedua, evaluasi layanan publik juga telah mengalami evolusi. Hal ini dihasilkan dari tanggung jawab terhadap desentralisasi, perpindahan kompetensi, dan hubungan akuntabilitas terhadap jenjang hirarki. Evaluasi atas pelaksanaan kebijakan publik tidak lagi hanya bertumpu pada ketaatan terhadap hukum dan regulasi. Pendekatan hukum selama ini telah mendominasi cara untuk menilai layanan publik oleh legislatif dan para politisi. Audit ketaatan, yang didasarkan pada gambaran ekonomi, merupakan metode alternatif yang dapat digunakan secara lebih baik. Fokus yang ingin diubah adalah dari seberapa banyak uang yang dibelanjakan menurut hukum dan regulasi atau peraturan ke arah apa yang terjadi dengan sumber daya yang ada, bagaimana mereka menggunakan, dan apa hasilnya bagi masyarakat. Informasi yang dihasilkan oleh sistem pengukuran kinerja akan menjadi bagian proses manajemen yang didefinisikan sebagai pelaksanaan tanggungjawab kinerja dari suatu sistem (Metcalfe, 1987). Hal itu digunakan sebagai elemen yang utama dalam mekanisme akuntabilitas administrasi atau hirarki politik.

Ketiga, perubahan arah penggunaan pengukuran kinerja oleh pihak manajemen. Indikator, ukuran, dan sistem pengukuran pada intinya tidak untuk menghukum atau memudahkan untuk melakukan tekanan. Ukuran yang baik dihasilkan dalam sistem dan proses yang selalu ditingkatkan. Ukuran kinerja dapat digunakan sebagai pedoman, pengendalian, dan evaluasi. Ukuran kinerja juga bermanfaat secara luas pada berbagai fungsi manajerial: keuangan, personalia, informasi, dan investasi.

Evolusi di atas telah mengarahkan penelitian-penelitian yang ada untuk menangkap maksud dan arah dari evolusi sistem pengukuran kinerja yang tengah bergulir. Penelitian-penelitian tersebut antara lain Roberts (1994) meneliti tentang keefektifan . sistem penilaian atau pengukuran kinerja dengan menggunakan voice variable (partisipasi, goal setting, dan umpan balik), validitas informasi, dan variabel moderator (karakteristik lain dalam penilaian, karakteristik organisasi, dan karakteristik másyarakatnya).

Sistem pengukuran kinerja yang baik memerlukan verifikasi lebih lanjut atas komponen-komponen yang harus ada di dalamnya. Komponen sistem pengukuran kinerja antara lain data, ukuran, dan sistem pengukurannya (Tuck, 1996). Dalam pengembangan sistem pengukuran kinerja harus memperhatikan karakteristik kualitatif atau kriteria komponen sistem. 
Karakteristik komponen tersebut harus dapat diuji kesahihannya (fit for use) hal ini dikaitkan dengan kerangka pemikiran sebagai alat untuk menjamin terselenggaranya proses pengukuran kinerja yang optimum (Will, 2000). Sistem pengukuran kinerja dikatakan dapat bekerja dan menghasilkan output yang optimum apabila memenuhi aspek-aspek validitas, legitimasi, dan fungsionalitas. Streib \& Poister (1999), menggunakan variabel validitas, fungsionalitas, dan legitimasi untuk mengukur tingkat optimalisasi sistem pengukuran kinerja pemerintah daerah (municipal govermment). Peneliti yang sama juga melakukan penelitian di U.S. mengenai pelaksanaan pengukuran kinerja di pemerintah daerah. Penelitian tersebut didisain untuk mempelajari bagaimana pemerintah daerah telah melakukan investasi pada pengembangan sistem pengukuran kinerja dan penerapan ukuran-ukuran dari sistem yang digunakan.

\section{Telaah Sistem Saat Ini}

Pemerintah daerah hingga saat ini, masih banyak yang menggunakan sistem yang dibangun berdasar pada Undangundang No. 5 tahun 1974 tentang Pokokpokok Pemerintahan di Daerah. Undangundang tersebut pada intinya berdasar pada tiga prinsip utama yaitu: prinsip desentralisasi, prinsip dekonsentrasi, dan prinsip tugas pembantuan. Hubungan fungsi dan keuangan antara pemerintah pusat dan daerah dibangun dengan dasar ketiga hal tersebut dan dievaluasi dengan menerapkan analisis varian terhadap anggaran dan realisasi anggaran yang sesungguhnya. Secara umum, hubungan tersebut tergambar pada gambar berikut.

\section{Gambar 1}

\section{Kerangka Hubungan Pusat-Daerah}

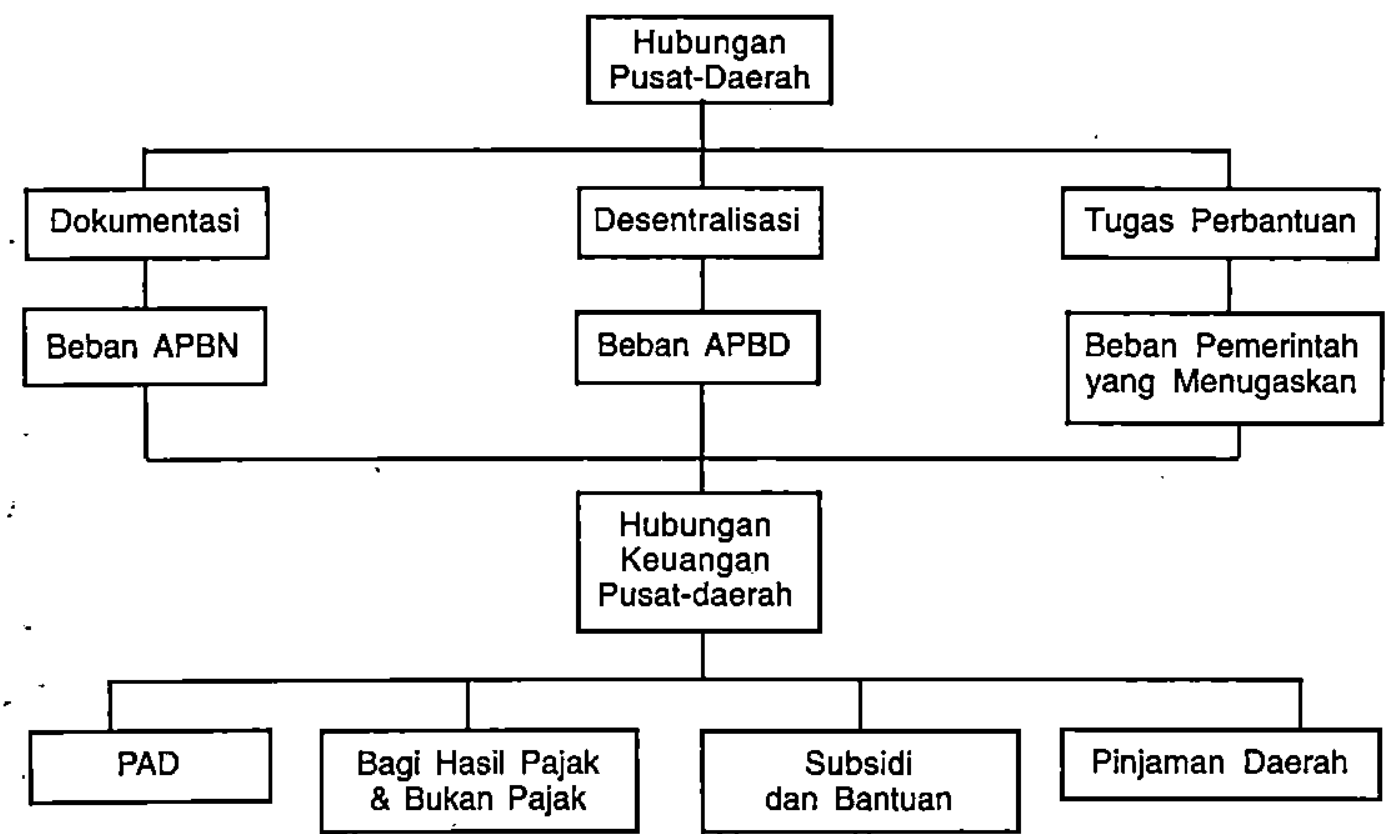

Sumber: Tesis Dr. Mardiasmo p. 79. 
Topik: Sistem Pengukuran Kinerja Sektor Publik: Telaah Kritis Terhadap..., Mardiasmo

\section{Sistem Penganggaran}

Secara umum, sistem penganggaran yang diterapkan selama ini memiliki beberapa karakteristik antara lain:

1. Dasar penyusunan yang digunakan bersifat incremental yaitu dengan menyesuaikan volume anggaran terhadap perubahan tingkat harga atau faktorfaktor lain yang bersifat marjinal. Metode ini berangkat dari asumsi bahwa secara keseluruhan keadaan masih seperti tahun lalu, sehingga menjadi metode yang paling mudah, murah, dan sederhana dalam menyusun anggaran.

2. Fungsi, program, dan elemen pengeluaran integral dengan struktur anggaran.

3. Sifat perencanaan dan anggaran terpisah. Keduanya tidak menjadi satu kesatuan yang integral.

4. Aspek evaluasi menggunakan aspek realisasi anggaran.

5. Orientasi anggaran lebih menekankan pada input daripada output.

6. Pendekatan perencanaan anggaran yang digunakan bersifat line-item budget yaitu perencanaan anggaran yang didasarkan atas "pos anggaran" yang telah ada sebelumnya.

7. Struktur anggaran menggunakan pendekatan anggaran terpilah (fragmented).

Sesuai dengan karakteristik entitas publik lainnya, pemerintah daerah secara keseluruhan cenderung menjadi cost center. Untuk itu pada bagian berikut perlu membahas kelompok pengeluaran atau belanja rutin dan belanja pembangunan sebagai komponen pada struktur anggaran daerah.

\section{Belanja Rutin}

Belanja rutin adalah pengeluaranpengeluaran pemerintah daerah yang ditujukan untuk membiayai kegiatan sehari- harinya. Secara khusus pengeluaran rutin dapat dibagi menjadi pengeluaran operasi dan pengeluaran konsumsi. Belanja rutin dibagi menjadi 10 (sepuluh) komponen; belanja pegawai, belanja barang, belanja pemeliharaan, belanja perjalanan dinas, belanja lain-lain, angsuran pinjaman/utang dan bunga, belanja pensiun, ganjaran/ subsidi, pengeluaran tidak termasuk bagian lain, dan pengeluaran tidak tersangka. Perbedaan komponen belanja rutin antara peraturan lama dan baru dapat dilihat pada Tabel 1.

Sebagian besar manfaat belanja rutin tidak langsung dirasakan masyarakat, namun secara langsung dinikmati aparatur daerah karena digunakan untuk belanja pegawai. Manfaat yang diharapkan dapat dinikmati masyarakat adalah berupa peningkatan pelayanan umum. Selama ini, satu-satunya ukuran kinerja yang dijadikan sebagai penilaian kinerja adalah jumlah maksimal yang dapat dibelanjakan untuk setiap pos pengeluaran rutin (Mardiasmo, 2002) dan hal tersebut merupakan tingkat penyerapan anggaran maksimal yang diharapakan dapat dicapai. Dengan demikian, suatu pemerintah daerah dikatakan memiliki kinerja yang baik jika pemerintah daerah maupun dinas mampu menggunakan secara keseluruhan item anggaran rutin (line-item) sesuai dengan proporsi anggaran yang telah disahkan atau dengan kata lain memiliki tingkat penyerapan anggaran yang maksimal.

Evaluasi atas pelaksanaan yang dijadikan dasar untuk penilaian kinerja dan penyusunan anggaran tahun berikutnya didasarkan pada analisis selisih atau varian dari anggaran dan realisasi sesungguhnya. Simplifikasi gambaran di atas ke dalam sistem pengukuran kinerja akan didapat gambaran adanya ukuran kinerja berupa ekonomi dan efisiensi. Ekonomi disebut juga sebagai kehematan yang berarti 
pengelolaan secara berhati-hati dan tidak terjadi pemborosan. Ekonomi merupakan praktik pembelian barang dan jasa sebagai input dengan tingkat kualitas tertentu. Sedangkan efisiensi menghendaki input dengan harga dan kualitas murah untuk menghasilkan barang atau jasa dengan kualitas tertentu. Dengan demikian, terdapat kesamaan antara pengertian ekonomi dan efisiensi yakni keduanya menghendaki adanya penurunan biaya.

\section{Belanja Pembangunan}

Belanja Pembangunan adalah pengeluaran pemerintah daerah yang bersifat investasi dan ditujukan untuk melaksanakan tugas-tugas pemerintah daerah. Bentuk belanja ini dapat berupa kegiatan pembangunan fisik seperti pembangunan jalan, jembatan atau gedung, dan dapat pula berupa pembangunan nonfisik berupa pendidikan, penelitian dan lain sebagainya. Belanja pembangunan tersebut umumnya dikelompokkan ke dalam 18 sektor. Sektor tersebut meliputi 1.Pertanian dan Irigasi, 2.Industri, 3.Pertambangan dan Energi, 4.Transportasi, 5.Perdagangan dan Koperasi, 6.Tenaga Kerja dan Koperasi, 7.Pembangunan Daerah, 8.Agama, 9.Pendidikan dan Kebudayaan NasionalKepercayaan terhadap Tuhan Yang Maha Esa-Pemuda dan Olahraga, 10.
Kependudukan dan Keluarga SejahteraKesehatan-Kesos-Peranan Wanita-Anak dan Remaja, 11.Perumahan dan Pemukiman, 12.Hukum, 13.Keamanan dan Ketertiban, 14.Penerangan-Komunikasi dan Media Masa, 15.llmu Pengetahuan, Riset dan Teknologi, 16.Aparatur Pemerintah dan Pengawasan, 17.Pengembangan Usaha, 18.Lingkungan dan Sumberdaya Alam.

Ukuran kinerja yang digunakan adalah jumlah dana pada setiap pos pengeluaran pembangunan yang tertera dalam Anggaran Daerah sebagai jumlah maksimal yang dapat dibelanjakan. Dengan demikian, jika terjadi pengeluaran rutin pemerintah daerah yang cenderung memerlukan dana yang besar, maka pada pengeluaran pembangunan hal yang sama juga dapat terjadi. Selain itu, evaluasi jenis belanja ini adalah apakah sudah sesuai dengan logik, penyusunan dan standar atau kriteria pencapaiannya.

Dengan menggunakan kerangka pemikiran yang sama pada belanja rutin di atas, maka belanja pembangunan memiliki ukuran sistemik berupa efektifitas. Suatu program pembangunan (fisik/non-fisik) dikatakan efektif bila proses kegiatan yang dilakukan mencapai tujuan dan sasarannya. Efektifitas merupakan hubungan antara keluaran dengan tujuan atau sasaran yang harus dicapai. 
Topik: Sistem Pengukuran Kinerja Sektor Publik: Telaah Kritis Terhadap..., Mardiasmo

Tabel 1

Struktur Belanja Lama dan Baru

\begin{tabular}{|c|c|}
\hline \multicolumn{2}{|c|}{ Struktur Belanja Menurut Peraturan Pemerintah No. 5 dan 6 tahun 1975} \\
\hline Belanja Rutin (10 komponen) & Belanja Pembangunan (18 sektor) \\
\hline $\begin{array}{l}\text { 1. Belanja Pegawai } \\
\text { 2. Belanja Barang } \\
\text { 3. Belanja Pemeliharaan } \\
\text { 4. Belanja Perjalanan Dinas } \\
\text { 5. Belanja Lain-lain. } \\
\text { 6. Angsuran pinjaman/Utang dan } \\
\text { Bunga } \\
\text { 7. Belanja Pensiun } \\
\text { 8. Ganjaran/Subsidi } \\
\text { 9. Pengeluaran Tidak Termasuk } \\
\text { Bagian Lain } \\
\text { 10. Pengeluaran Tidak Tersangka }\end{array}$ & $\begin{array}{l}\text { 1. Pertanian dan Irigasi, 2. Industri, 3. Pertambangan } \\
\text { dan Energi, 4.Transportasi, 5. Perdagangan dan } \\
\text { Koperasi, 6.Tenaga Kerja dan Koperasi, 7. } \\
\text { Pembangunan Daerah, 8. Agama, } 9 \text {. Pendidikan } \\
\text { dan Kebudayaan Nasional-Kepercayaan terhadap } \\
\text { Tuhan Yang Maha Esa-Pemuda dan Olahraga, } 10 . \\
\text { Kependudukan dan Keluarga Sejahtera-Kesehatan- } \\
\text { Kesos-Peranan Wanita-Anak dan Remaja, 11. } \\
\text { Perumahan dan Pemukiman, 12. Hukum, 13. } \\
\text { Keamanan dan Ketertiban, 14. Penerangan- } \\
\text { Komunikasi dan Media Masa, 15. Ilmu Pengetahuan, } \\
\text { Riset dan Teknologi, 16. Aparatur Pemerintah dan } \\
\text { Pengawasan, 17. Pengembangan Usaha, } \\
\text { 18.Lingkungan dan Sumberdaya Alam }\end{array}$ \\
\hline
\end{tabular}

Struktur Belanja Menurut Peraturan Pemerintah No. 105 dan 108 Tahun 2000

\begin{tabular}{|c|c|}
\hline Belanja Rutin & Belanja Pembangunan \\
\hline $\begin{array}{l}\text { a. Belanja Aparatur Daerah } \\
\text { 1. Administrasi Umum; Pegawai/Personalia, } \\
\text { Barang dan Jasa, Perjalanan Dinas, dan } \\
\text { Pemeliharaan } \\
\text { 2. Operasi dan Pemeliharaan; } \\
\text { Pegawai/Personalia, Barang dan Jasa, } \\
\text { Perjalanan Dinas, dan Pemeliharaan } \\
\text { b. Belanja Pelayanan Publik } \\
\text { 1. Administrasi Umum; Pegawai/Personalia, } \\
\text { Barang dan Jasa, Perjalanan Dinas, dan } \\
\text { Pemeliharaan } \\
\text { 2. Operasi dan Pemeliharaan; } \\
\text { Pegawai/Personalia, Barang dan Jasa, } \\
\text { Perjalanan Dinas, dan Pemeliharaan } \\
\text { c. Belanja Bagi Hasil dan Bantuan Keuangan } \\
\text { d. Belanja Tidak Tersangka }\end{array}$ & $\begin{array}{l}\text { a. Belanja Aparatur Daerah } \\
\text { - Belanja Modal } \\
\text { b. Belanja Pelayanan Publik } \\
\text { - Belanja Modal. }\end{array}$ \\
\hline
\end{tabular}


Topik: Sistem Pengukuran Kinerja Sektor Publik: Telaah Kritis Terhadap..., Mardiasmo

\section{Sistem Akuntansi}

Sistem akuntansi yang digunakan selama ini merujuk pada undang-undang yang sama seperti pada anggaran di atas, memilikj karakteristik inheren antara lain:

1. Sistem pembukuan bersifat tunggal (single entry).

2. Sistem akuntansi berbasis kas.

3. Belum menyediakan media pencatatan untuk kategori pengeluaran modal.

4. Laporan pertanggungjawaban lebih terfokus pada pertanggungjawaban administratif.

5. Proses pertanggungjawaban belum melibatkan auditor ekstemal.

Bila dilihat dari aspek sistem pengendalian intern, sistem akuntansi di atas mengharuskan pelimpahan wewenang otorisasi pada kebijakan Kepala Daerah. Selain itu, belum juga mengenal kebijakan akuntansi. Sistem tersebut telah memiliki deskripsi mengenai pendapatan dan belanja, namun belum memiliki deskripsi neraca.

Jenis Laporan yang disusun hanya Laporan Anggaran Pendapatan dan Belanja
Daerah (APBD) yang berisi anggaran/target dan realisasinya. Adapun penyajiannya dalam format Laporan Penetapan APBD, Laporan Perubahan APBD, dan Laporan Perhitungan APBD. Penyusunan formulir, dokumen, buku besar, dan buku pembantu belum baik dan terkesan tumpang tindih.

Prosedur-prosedur akuntansi atau flowchart belum disusun dengan baik. Prosedur yang ada lebih menekankan pada tata pembukuan tentang petunjuk pengisian dokumen, buku, dan catatan. Bentuk dan susunan kode rekening untuk pendapatan, belanja, dan neraca juga belum ada.

Gambaran mengenai sistem anggaran dan sistem akuntansi di atas bila kemudian dirumuskan ke dalam tataran sistemik (sistem pengukuran kinerja) akan menjadi sistem pengukuran kinerja dengan menggunakan beberapa indikator dan ukuran sebagai dasar penilaian kinerja. Untuk lebih memudahkan pemahaman tentang sistem pengukuran kinerja yang ada sesuai peraturan yang ada (PP. No 5 dan 6 tahun 1975) maka rumusan simplifikasi peraturan yang ada tersebut adalah:

\section{Gambar 2 .}

\section{Sistem Pengukuran Kinerja Pemerintah Daerah}

\begin{tabular}{|c|c|c|c|}
\hline Belanja & $\begin{array}{l}\text { Indikator } \\
\text { (What) }\end{array}$ & & $\begin{array}{l}\text { Ukuran } \\
\text { (How Well) }\end{array}$ \\
\hline \multirow[t]{2}{*}{ Rutin } & Nilai Input & Ekonomi & \multirow[t]{2}{*}{$\begin{array}{l}\text { Tingkat Penyerapan } \\
\text { Anggaran }\end{array}$} \\
\hline & Output & Efisiensi & \\
\hline \multirow[t]{2}{*}{ Pembangunan } & Output & Efektifitas & \multirow[t]{2}{*}{$\begin{array}{l}\text { Logik Penyusunan } \\
\text { dan Kriteria Pencapaian }\end{array}$} \\
\hline & Outcomes & & \\
\hline
\end{tabular}


Reformasi yang tengah bergulir mendorong pemerintah untuk mengembangkan indikator kinerja pemerintah daerah yang diawali oleh Menteri Dalam Negeri sejak tahun 1980-an hingga awal 1990-an. Pada saat, itu Menteri Dalam Negeri bekerjasama dengan Universitas Gadjah Mada berusaha mengembangkan suatu indikator yang mampu menunjukkan kemampuan pemerintah daerah dalam menerapkan otonomi dan desentralisasi fiskal.

Lembaga Administrasi Negara (LAN) melanjutkan usaha di atas dengan mulai mengembangkan sistem pemeringkatan pemerintah daerah untuk menilai kemampuan pemerintah daerah dalam melaksanakan otonomi. Dalam hal ini berupa indikator yang digunakan untuk menilai otoritas tambahan yang mungkin ditransfer kepada pemerintah daerah dan jenis bantuan teknis apa saja yang diperlukan. Indikator tersebut mencakup empat fungsi yaitu perencanaan dan pemrograman, mobilisasi sumber daya, manajemen dan penganggaran, disain, dan implementasi proyek.

Usaha tersebut di atas berlanjut dengan adanya Inpres No.7 tahun 1999 yang mengharuskan eselon II ke atas untuk menyiapkan Laporan Akuntabilitas Kinerja yang kemudian dikenal sebagai Laporan Akuntabilitas Kinerja Instansi Pemerintah (LAKIP). Eselon II dan yang lebih tinggi diharuskan untuk menyusun indikator, metode, dan mekanisme pelaporan atas kinerja instanși pemerintahnya. Namun demikian, masih banyak kendala terutama pada teknis pelaksanaannya.

Aturan baru yang berkaitan dengan masalah pengukuran kinerja antara lain UU 22 tahun 1999, UU 25 tahun 1999, PP 105 tahun 2000, dan PP 108 tahun 2000. PP 108 tahun 2000 mengharuskan Kepala Daerah menyampaikan Laporan Pertanggungjawaban Keuangan Daerah yang terdiri dari Laporan Perhitungan APBD, Nota Perhitungan APBD, Laporan Aliran Kas, dan Neraca Daerah yang didasarkan pada pengukuran kinerja yang berbasis rencana strategik. PP 105 tahun 2000 menggunakan empat proksi sebagai alat pengukuran kinerja pemerintah daerah yaitu standar pelayanan, standar analisa belanja, tolok ukur kinerja, dan standar biaya.

Pada tataran normatif hal ini masih banyak ditemui kesulitan yang disebabkan oleh pedoman teknis yang belum ada. Ilustrasi terhadap regulasi di atas dapat diidentifikasikan sebagai berikut: 
Topik: Sistem Pengukuran Kinerja Sektor Publik: Telaah Kritis Terhadap..., Mardiasmö

\section{Gambar 3}

Sistem Akuntabilitas Kinerja

\begin{tabular}{|c|c|}
\hline \multirow{13}{*}{ 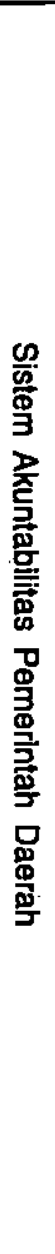 } & Pemerintah Daerah \\
\hline & Rencana Strategik \\
\hline & Sasaran \\
\hline & Alat Ukur Kinerja \\
\hline & Alat Ukur Kinerja Keuangan dan Non-Keuangan \\
\hline & $\begin{array}{l}\text { Laporan Keuangan Daerah dan Analisis atas Laporan Keuangan Daerah: } \\
\text { 1. Laporan Perhitungan APBD } \\
\text { 2. Nota Perhitungan APBD } \\
\text { 3. Laporan Aliran Kas } \\
\text { 4. Neraca Daerah }\end{array}$ \\
\hline & Unit Kerja/Dinas \\
\hline & Rencana Strategik \\
\hline & Tugas Pokok dan Fungsi Tupoksi \\
\hline & Sasaran \\
\hline & Alat Ukur Kinerja \\
\hline & Alat Ukur Kinerja Keuangan dan Non-Keuangan \\
\hline & $\begin{array}{l}\text { a. Standard Pelayanan Masyarakat: indikatornya berupa. } \\
\text { outcome, benefit, dan impact } \\
\text { b. Kriteria Kinerja: mengacu pada indikator output, can outcome } \\
\text { c. Standard analisa belanja: mengacu pada indikator input dan output. } \\
\text { d. Standard biaya: pengukuran input } \\
\text { Berdasar pada prinsip value for money; economy, efficiency, effectiveness }\end{array}$ \\
\hline
\end{tabular}

Sistem akuntabilitas kinerja pemerintah di atas merupakan suatu instrumen pertanggungjawaban yang terdiri dari berbagai indikator dan mekanisme aktivitas untuk pengukuran, penilaian, dan pelaporan atas kinerja pemerintah dalam suatu cara yang komprehensif dan terintegrasi.

\section{Membangun Akuntabilitas Kinerja}

Akuntabilitas tidak begitu saja terjadi. Akuntabilitas harus dibangun, pertama melalui suatu lingkungan yang memiliki akuntabilitas, kemudian melalui suatu kerangka kerja akuntabilitas. Lingkungan mengintegrasikan akuntabilitas dalam individu, tim, dan sistem kinerja organisasi. Sedangkan kerangka kerja memastikan pelaksanaan dan pemenuhan atas 
kewajiban akuntabilitas. Bagian berikut akan mengupas keduanya secara lebih mendalam.

\section{Akuntabilitas Lingkungan?}

Akuntabilitas lingkungan mengacu pada kondisi dimana di dalamnya akuntabilitas dapat berjalan dengan baik. Secara khusus, suatu lingkungan yang memiliki akuntabilitas adalah adanya kondisi dimana di dalamnya individu, tim, dan organisasi merasa:

a. Termotivasi untuk melaksanakan wewenang mereka dan/atau memenuhi tanggungjawab;

b. Mendorong untuk melaksanakan kerja mereka dan mencapai hasil yang diinginkan;

c. Memberikan inspirasi untuk membagi (melaporkan) hasil mereka; dan

d. Kemauan untuk menerima kewajiban atas hasil tersebut.

Lingkungan akuntabilitas yang optimal merupakan salah satu akuntabilitas yang proaktif dimana di dalam individu, tim, dan organisasi memiliki fokus pada pencapaian hasil yang besar daripada sekedar menggambarkan cara-cara untuk menjelaskan hasil yang buruk yang diperoleh. Untuk banyak bagian, lingkungan yang memiliki akuntabilitas dibangun dari atas ke bawah seperti institusi kepemimpinan organisasional dan promosi lingkungan dan menurunkannya ke dalam berbagai jenjang manajemen ke bawah hingga ke individu pekerja. Dengan demikian, "kesulitan/ masalah" yang terkait dengan lingkungan akuntabilitas pada individu pekerja biasanya dapat dilacak hingga ke lingkungan yang terpengaruh di dalam jenjang manajemen. Meskipun demikian, ada jeda waktu ketika individu pekerja mengabaikan dukungan dan komitmen manajemen. Ada beberapa komponen yang penting untuk menyusun sistem pengukuran kinerja yang terintegrasi, namun tidak dibahas pada kesempatan ini. Ada beberapa persyaratan yang harus dipenuhi untuk menyusun akuntabilitas lingkungan yang sukses; Leadership, Reciprocation, Equity, Trust, Transparency, Clanity, Balance, Ownership, Consequences, Consistency, dan Follow-Up.

\section{Kepemimpinan}

Kepemimpinan menjadi hal yang penting dalam suatu lingkungan. Kepemimpinan diacu sebagai individu atau group dalam suatu posisi yang memiliki wewenang untuk mengarahkan dan mengendalikan pekerjaan orang lain. Sesuatu mengenai kepemimpinan yang dapat dilaksanakan untuk membangun dan memperkenalkan akuntabilitas lingkungan adalah:
a. Mengarahkan dengan contoh.
b. Harus memiliki komitmen.
c. Jalur yang bersih.
d. Menjadi seorang yang mampu menja- wab yang baik/menjadi tempat bertanya.
e. Menggunakan pertimbangan yang bijakșana/baik.

\section{Reciprocation}

Reciprocal accountability memastikan bahwa "two-wayness"hubungan akuntabilitas berjalan dengan baik. Hal itu menjamin keterbukaan dan mendorong baik transparansi maupun kejelasan (clarity). Dengan menggunakan konsep reciprocal accountability, seseorang atau group atau organisasi dengan yang menerima wewenang dan orang, group, organisasi yang menerima delegasi tanggungjawab akan dapat melaksanakan apa yang dimaksud dengan quid pro quo relationship. Yakni yang memiliki wewenang bertanggungjawab untuk memberikan kecukupan arahan, pedoman, dan sumber daya begitu juga usaha untuk 
menghilangkan/mengurangi halangan kinerja.

Di lain pihak, yang menerima delegasi, bertanggungjawab melaksanakan pemenuhan tanggungjawab tersebut. Dalam hubungan ini tersebut, keduanya saling memiliki akuntabilitas masing-masing. Apsek kunci dari reciprocal accountability adalah senior manajamen masuk dalam akuntabilitas yang sejajar dengan bawahan, atau dengan kata lain senior manajemen masuk dalam persamaan akuntabilitas. Seperti yang digambarkan oleh the Citizens Circle for Accountability (1996), dalam Konteks reciprocal accountability "orang yang memiliki wewenang yang senior dalam suatu organisasi akan bersedia menjawab pada anggota organisasi anggotanya mengenai apa yang mereka hendak tuju, untuk siapa mereka bekerja, dan untuk apa kontribusi pemikiran mereka". Dengan kata lain, mereka menjadi partisipan dan bukan sekedar pengikut dibelakang saja.

\section{Equity}

Equity or faimess (kewajaran) merupakan pusat perhatian dari konsep akuntabilitas. Asumsi terhadap keterbukaan akuntabilitas harus selalu dipelihara dan didukung oleh kepemimpinan organisasi. Ketidakwajaran seharusnya dihindari karena hal itu akan merusak kepercayaan dan kredibilitas organisasi. Dan sebagai akibatnya kinerja organisasi kurang optimal.

\section{Kepercayaan}

Kewajaran akan mangarah pada kepercayaan; kepercayaan menunjukkan adanya kewajaran. Tidak akan dapat dibangun hubungan akuntabilitas tanpa adanya kepercayaan. Jika satu atau dua bagian/pihak saling tidak percaya satu sama lain maka ada kemungkinan kelemahan transparansi, dan hubungan yang demikian akan meng- alami kegagalan. Dengan kata lain, akuntabilitas tidak dapat beriangsung dalam lingkungan yang tidak ada saling kepercayaan.

\section{Transparansi}

Transparansi menupakan kondisi adanya keterbukaan secara penuh, juga merupakan salah satu elemen penopang akuntabilitas. Dengan demikian, transparansi merupakan kunci untuk membangun lingkungan yang memiliki akuntabilitas. Transparansi berarti bahwa individu, group, atau organisasi dalam hubungan akuntabilitas diarahkan tanpa adanya kebohongan atau motivasi yang tersembunyi, dan bahwa seluruh informasi kinerja lengkap dan tidak memiliki tujuan menghilangkan data yang berhubungan dengan masalah tertentu. Dalam istilah yang sederhana transparansi berarti "seluruh pemain meletakkan seluruh kartu mereka di atas meja". Lingkungan tanpa transparansi berarti ada suatu agenda yang tersembunyi. Juga berarti suatu lingkungan yang tidak memiliki kepercayaan dan memiliki akuntabilitas yang rusak.

\section{Kejelasan}

Kejelasan juga merupakan salah satu elemen penopang akuntabilitas. Agar individu atau group melaksanakan wewenang danvatau memenuhi tanggungjawab, mereka perlu gambaran yang jelas mengenai apa saja yang mereka akan laksanakan/penuhi dan hasil apa yang diharapkan. Dengan demikian fokus yang menjadi kunci kejelasan adalah:

a. Otoritas/wewenang, otoritas adalah hak untuk bertindak tanpa persetujuan awal dari manajemen yang lebih tinggi dan tanpa tantangan dari sesama manajemen (Frost, 1998). Individu-individu dan grup di dalam organisasi harus tahu 
siapa yang berwenang dan tingkat wewenang yang mereka miliki. Dengan kata lain, mereka mampu membedakan' garis otoritas organisasi, memahami gambaran yang jelas tentang struktur pelaporan organisasi. Sebagai tambahan, bagi mereka yang menerima wewenang mereka juga harus tahu derajat wewenang mereka agar dapat memahami apa yang seharusnya dan yang tidak sehanusnya mereka perlu jawab/kerjakan.

b. Misi Organisasi, individu dan group pertu memiliki pemikiran yang jelas mengenai misi organisasi dan peran yang mereka mainkan dalam pencapaian misi. Termasuk misi divisi, departemen, dan/ atau tim yang menjadi bahan bagi misi organisasi secara keseluruhan. Individu dan group yang melaksanakan kerja tanpa pemahaman mengenai tujuan dan arah organisasi maka tidak akan efisien atau efektif, begitu juga mereka yang tidak memiliki rasa kepemilikan.

c. Peran dan Tanggungjawab, agar supaya individu atau grup memenuhi tanggungjawabnya, mereka perlu mengetahui (1) peran apa yang mereka mainkan dalam misi organisasi (2) apa tanggung-jawab mereka dalam misi organisasi. The Auditor General of Canada and the Treasury Board Secretariat (1998) mengatakan: "Perlu memahami dengan baik peran dan tanggungjawab bagianbagian yang terlibat dalam suatu hubungan akuntabilitas. Pemahaman yang baik akan memberikan suasana yang baik pada pihak-pihak yang merespon maupun yang melaksanakan."

d. Ekspektasi Kinerja, individu dan grup harus mengetahui secara pasti apa yang diharapkan dari mereka atas kinerjanya jika mereka akan melaksanakan suatu tanggung-jawab dan ditanya terhadap pelaksanaan dan pemenuhan tanggungjawab dan penerimaan kewajiban atas hasil yang mereka capai. Jika ekspektasi kinerja tidak jelas, 'maka kemudian identifikasi akuntabilitas juga tidak akan jelas. Mencoba mengendalikan - orang atau group untuk hasil yang mereka tidak mengetahui ekspektasinya akan menjadi sesuatu yang sulit atau tidak dapat dicapai.

e. Pelaporan Kinerja, hasil kinerja perlu untuk dilaporkan secara jelas dan tanpa bias, apalagi jika informasi digunakan untuk mendorong peningkatan organisasi. Seperti yang dikatakan oleh Auditor General of Canada and the Treasury Board Secretariat (1998), "Akuntabilitas yang efektif memerlukan pelaporan (akuntansi) terhadap apa yang sudah dicapai. Laporan harus memiliki kredibilitas, berguna dan harus tepat waktu: Hasil pencapaian itu harus digambarkan dan diintegrasikan dalam beberapa cara bagi yang memiliki wewenang, sumberdaya, dan tindakantindakannya, disajikan dalam ekspektasi yang disepakati, dan dilaporkan dalam kerangka waktu yang masuk akal."

\section{Keseimbangan}

Agar akuntabilitas berjalan dengan baik harus ada keseimbangan antara akuntabilitas dan wewenang/otoritas; ekspektasi dan kapasitas; dan upah dan kinerja.

a. Akuntabilitas dan otoritas, The Auditor General of British Columbia (1996) mencatat, "Adalah menjadi lemah kalau mengendalikan program-program manajer dan-akuntabilitas eksekutif atas kinerjanya jika mereka tidak memiliki otoritas untuk melaksanakan tindakan yang penting untuk mencapai kinerja. Suatu perubahan/peningkatan yang subtansial bagi kinerja suatu organisasi harus disertai dengan perubahan yang penting yaitu otoritas." 
b. Ekspektasi dan kapasitas, suatu poin penting yang 'dibuat oleh Auditor General of Canada and the Treasury Board Secretariat (1998) adalah bahwa ekspektasi kinerja "perlu dihubungkan secara jelas dengan keseimbangan dengan kapasitas (otoritas, keahlian, dan sumber daya) dari setiap bagian organisasinya." Kegagalan dalam membangun hubungan yang wajar atau yang masuk akal antara apa yang diharapkan dengan wewenang dan sumber daya yang diberikan, cenderung akan menggerogoti efektifitas akuntabilitas. Ekspektasi yang berada di luar kewajaran akan memberikan ketidakyakinan dalam pencapaiannya. Sesuai dengan pemikiran di atas, efektifitas akuntabilitas dapat ditingkatkan dengan membangun suatu kerangka hubungan yang jelas atas hubungan dan keseimbangan antara sumberdaya dan ekspektasi hasil-hasilnya.

c. Upah dan kinerja, tantangan yang nyata bagi lingkungan yang memiliki akuntabilitas adalah ketidakseimbangan antara apakah individu dibayar untuk kinerjanya dan apakah individu diharapkan untuk melaksanakannya. Upah yang rendah dengan ekspektasi yang tinggi akan menurunkan moral. Upah yang tinggi dengan ekspektasi. yang rendah akan membuat seseorang menjadi tidak memiliki inspirasi dan motivasi bekerja yang baik. Harus ada keseimbangan antara keduanya.

\section{Ownership}

Kinerja yang optimal dapat dicapai dengan memberikan rasa kepemilikan atas setiap tindakan pada individu-individu dan group. Kepemilikan memberikan suatu kepentingan atas outcomes dan dengan demikian akan mengarahkan mereka untuk bertindak dalam bisnis secara berhati-hati (guna memenuhi tanggung-jawab). Dengan kata lain, rasa pemilikan akan meningkatkan perilaku, tanggung-jawab, dan sikap. Pengembangan rasa memiliki pada individu dan group dicapai melalui proses yang disebut "menting." Adapun bagian dari proses tersebut antara lain:

a. Komitmen, Komitmen merupakan poin awal dalam pemilikan. Manajemen harus menunjukkan pada individu atau group dan juga harus memperoleh komitmen mereka untuk mencapai ekspektasi kinerja. Komitmen manajer pada individu dan group menunjukkan rasa pemilikan manajemen terhadap tindakan dan outcomes individu dan group. Ilustrasi tersebut merupakan contoh kasus kepemimpinan.

b. Pesetujuan, Karena akuntabilitas merupakan suatu hubungan atau kontrak antara dua bagian, persetujuan terhadap hubungan akuntabilitas (otoritas, peran dan tanggung-jawab, ekspektasi kinerja, syarat/kriteria pelaporan, dan konsekuensi) seharusnya disetujui terlebih dahulu sebelum kerja dilaksanakan. Jika ada persetujuan, maka akan ada kejelasan dan pemahaman yang lebih baik. Tanpa hal itu maka akan muncul ketidakpastian dan ketiadaan akuntabilitas. Sebagai tambahan persetujuan tersebut akan membuat seseorang atau group memiliki rasa memiliki kontrak.

c. Keterlibatan, Keterlibatan dalam proses perencanaan dan proses pelaksanaan kerja, dan aktivitas-aktivitas lain akan mampu membangun rasa pemilikan dan bertanggung-jawab (buy in) terhadap proses dan aktifitas tersebut (involvement). Selain meningkatkan rasa pemilikan, keterlibatan juga akan meningkatkan loyalitas dan komitmen yang pada akhirnya meningkatkan akuntabilitas. 
d. Pemberdayaan, Pemberdayaan dibbaratkan sebagai pertalian darah atas pembagian wewenang antara manajemen dengan individu dan group. Ketika ekspektasi kinerja didefinisikan dan disetujui, manajemen memberikan bantuan pada individu dan group yang memiliki kekuatan di lapangan untuk menjalankan persetujuan sesuai dengan ekspektasinya dalam kerangka kerja yang diberikan. Pemberdayaan individu dan group merupakan bentuk keterlibatan dan hal ini menciptakan rasa pemilikan dan meningkatkan komitmen.

e. Investasi, Tingkat investasi organisasi (pelatihan, sumberdaya kerja, upah dan sebagainya) pada karyawan menunjukkan suatu tingkatan bahwa organisasi memiliki komitmen pada karyawan. Tingkat dimana karyawan merasa memiliki akan menunjukkan tingkat bahwa ia memiliki pekerjaan mereka.

f. Usaha yang berkelanjutan, Usaha yang berkelanjutan akan memberikan pada karyawan peluang untuk berbuat lebih baik, dan hanya dengan jalan tersebut keberlangsungan kerja saat ini akan meningkat dan akan menunjukkan kemampuan untuk mencapai kemampuan kerja yang lebih. Peluang untuk keberlanjutan akan mendorong karyawan berbuat lebih baik dan meningkatkan rasa pemilikan terhadap lingkungan sekitar.

g. Penghargaan, Penghargaan kinerja merupakan kunci akuntabilitas lingkungan. Ini merupakan salah satu konsekuensi akuntabilitas. Ketika karyawan mengetahui penghargaan erat kaitannya dengan kinerja mereka, maka mereka akan komit terhadap pelaksanaan kinerja dan memiliki rasa pemilikan terhadap setiap tindakannya. Biasanya jika karyawan dihargai secara baik atas kinerjanya, maka mereka akan me- ngembangkan sense pencapaian/ pemenuhan yang akan membuat mereka bangga dalam pekerjaan mereka dan akan meningkatkan rasa pemilikan.

\section{Konsekuensi}

Akuntabilitas akan kurang bermakna tanpa adanya konsekuensi. Akuntabilitas lahir bersama dengan kewajiban dan kewajiban lahir bersama dengan konsekuensi. Konsekuensi dapat berupa penghargaan (baik) atau sanksi (buruk). Apapun kasusnya, konsekuensi membantu mendorong pelaksanaan wewenang, pemenuhan tanggung-jawab, dan peningkatan kinerja. Membangun kerangka konsekuensi jika tidak berjalan sesuai dengannya arah kerangka tersebut maka akan memiliki dampak yang dapat menurunkan makna dan tingkat pentingnya akuntabilitas.

\section{Konsistensi}

Konsistensi menjamin stabilitas. Penerapan yang inkonsisten terhadap kebijakan, prosedur, sumberdaya, dan/atau konsekuensi dalam suatu organisasi menurunkan atau melemahkan akuntabilitas lingkungan dan kredibilitasnya. Hal itu menurunkan moral karyawan dan mendorong munculnya sinisme. Rasa memiliki akan hilang dan kinerja akan melemah.

\section{Tindak Lanjut (Follow-Up)}

Dalam dokumen, Modernizing ACcountability Practices in the Public Sector (1998), the Auditor General of Canada and the Treasury Board Secretariat mengacu hal berikut "Reasonable review and adjustment," nothing that, "Something has to happen as a result of reporting accountability information in order to 'close the loop". Bagian-bagian yang melakukan reviewatas hasil memerlukan pertimbangan apakah pencapaian hasil tersebut sesuai dengan 
ekspektasinya dan lingkungan yang ada, dan kemudian mengakuinya sebagai usaha yang tercapai sepenuhnya. Jika ekspektasi tidak sesuai maka perlu tindakan koreksi dan kemungkinan penyesuaian untuk penyusunan akuntabilitas yang dibuat dan memberikan catatan atas usaha pembelajaran. Hubungan akuntabilitas tanpa adanya follow-up merupakan hasil yang jelas tidak lengkap dan tidak efektif.

\section{Halangan Akuntabilitas Lingkungan}

Pada bagian ini akan dikemukakan halangan terhadap adanya akuntabilitas lingkungan - yaitu sesuatu yang yang menjadi counter-productive untuk menciptakan kesehatan dan hubungan akuntabilitas yang efektif. Berikut gambaran beberapa hal yang biasanya akan terjadi yang dapat menghambat akuntabilitas.

1. Agenda atau rencana yang tidak transparan. Agenda atau rencana yang disusun secara tidak transparan akan mengarahkan organisasi dalam suatu kondisi yang hanya menguntungkan perseorangan. Taktik yang demikian, hanya akan membuat karyawan akan meninggalkan tanggungjawab dan tidak memotivasi untuk melaksanakan tanggungjawab tersebut. Taktik ini juga akan merusak kepercayaan yang sudah dibangun, dimana kepercayaan merupakan elemen kunci akuntabilitas. Ingat bahwa akuntabilitas mensyaratkan transparansi dan transparansi berarti keterbukaan.

2. Favoritism-favoritism merupakan isu yang licik. Manajemen dapat saja melakukan kinerja secara lebih unggul dan meninggalkan karyawan yang lainnya. Atau manajemen dapat merugikan karyawan yang mengarah pada kinerja yang kurang baik, juga membebani karyawan secara berlebih. Akuntabilitas memerlukan inklusivitas dan kerja tim. Favoritism tidak mendukung kedua hal tersebut.

3. Kepemimpinan yang lemah. Komitmen kepemimpinan untuk membangun suatu lingkungan yang memiliki akuntabilitas merupakan hal yang krusial. Tanpa kepemimpinan yang kuat, hasil kinerja akan kurang dari yang diharapkan.

4. Kekurangan sumber daya. Hal ini akan menjadi kurang berguna jika individu atau tim tidak didukung sumber daya untuk melaksanakan pekerjaannya. Untuk memperoleh hasil yang baik atas kinerjanya, organisasi harus melakukan investasi pada karyawan mereka.

5. Lack of Follow-Through. Ketika manajemen mengatakan bahwa mereka akan mengerjakan sesuatu dan mereka tidak mengerjakan sesuatu itu, hal ini mengatakan pada karyawan bahwa manajemen tidak dapat dipercaya untuk menindaklanjuti. Sebagai contoh, informasi penghargaan atau hukuman untuk kinerja dan kemudian tidak ditindak lanjuti, hal akan memberi kesan bahwa manajemen tidak dapat dipercaya. Hal ini juga tidak memberikan inspirasi pada karyawan untuk melaksanakan pekerjaannya.

6. Kurang Jelas. Ketika garis antara wewenang dan tanggungjawab tidak jelas, sulit untuk menentukan letak akuntabilitasnya. Hal ini juga mengarahkan pelaksanaan atas kewajiban kinerja menjadi tidak terarahi. Kejelasan merupakan inti suatu bentuk hubungan akuntabilitas.

7. Kesalahan Penggunaan Data. Informasi kinerja harus lengkap dan memiliki kredibilitas, dan hal itu harus dilaporkan secara tepat waktu. Dengan menggunakan data akan dapat menunjukkan kelemahan transparansi dan ketidak- 
Topik: Sistem Pengukuran Kinerja Sektor Publik: Telaah Kritis Terhadap..., Mardiasmo

percayaan. Tanpa menggunakan data secara menyeluruh akan mendatangkan pemahaman yang kurang bermakna atas kinerja dan hal ini akan menjadi tidak berarti bagi organisasi.

\section{Membangun Kerangka Kerja Akuntabilitas}

Ketika individu atau organisasi menerima wewenang dan/atau delegasi tanggungjawab, mereka harus menyusun rencana, melaksanakan rencana, dan mengukur serta melaporkan hasil yang nyata dibandingkan dengan rencana yang telah disusun. Penerimaan laporan ini akan menghasilkan umpan balik, rencana baru unutuk pengembangan berikutnya, dan siklus ban. Siklus ini memberikan dasar kerangka kerja untuk akuntabilitas. Contoh dari siklus ini adalah kerangka kerja yang disajikan dalam dokumen Auditor General of Alberta's document, Government Accountability (1997). Lima langkah kerangka kerja akuntabilitas seperti yang ada di bawah ini:

1. Menyusun tujuan yang terukur dan tanggung-jawab. Mengikuti rencana strategik kemudian mengembangkan sasaran, ukuran-ukuran, dan ekspekta- sinya. Identifikasi peran dan tanggungjawab dalam hubungan pencapaian ekspektasi tersebut.

2. Rencana apa yang diperlukan untuk melaksanakan pencapaian tujuan. Identifikasi tindakan apa yang diperlukan untuk dilaksanakan oleh seseorang, pada waktu apa/kapan, dan berapa biayanya. Identifikasi sumberdaya yang penting yang diperlukan untuk mencapai tujuan. Indentifikasi konsekuensikonsekuensi yang timbul dan yang mungkin timbul.

3. Melaksanakan pekerjaan dan memonitor perkembangannya. Melaksanakan kerja dan pengukuran perkembangarnya. Mengumpulkan dan menganalis data kinerja.

4. Laporan Hasil. Menyiapkan secara lengkap, dapat dipahami, dan laporan yang nyata pada hasil kinerja dan mendistribusikan pada pihak yang berkepentingan tepat waktu.

5. Evaluasi hasil dan mengusahakan umpan balik. Evaluasi hasil untuk menunjukkan apakah tindakan koreksi diperlukan untuk meningkatkan kinerja atau untuk menunjukkan penghargaan yang harus diberikan bagi kinerja yang efisien dan efektif.

Gambar 4

Kerangka Akuntabilitas

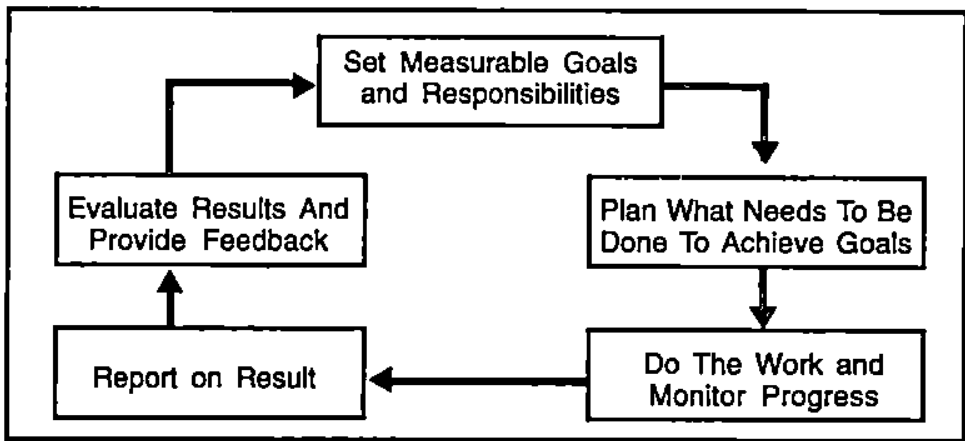

Sumber: Will Artley, Establishing Accountability for Performance, p. 17. 
Topik: Sistem Pengukuran Kinerja Sektor Publik: Telaah Kritis Terhadap..., Mardiasmo

Gambaran yang jelas dān sangat baik strategik, rangkaian tujuan kinerja, dan dapat diperoleh juga dari kerangka kerja laporan tahunan berdasar kinerja aktual Government Performance and Results Act yang dibandingkan dengan tujuannya (lihat of 1993 (GPRA). GPRA mensyaratkan agensi untuk mengembangkan rencana Gambar 5)

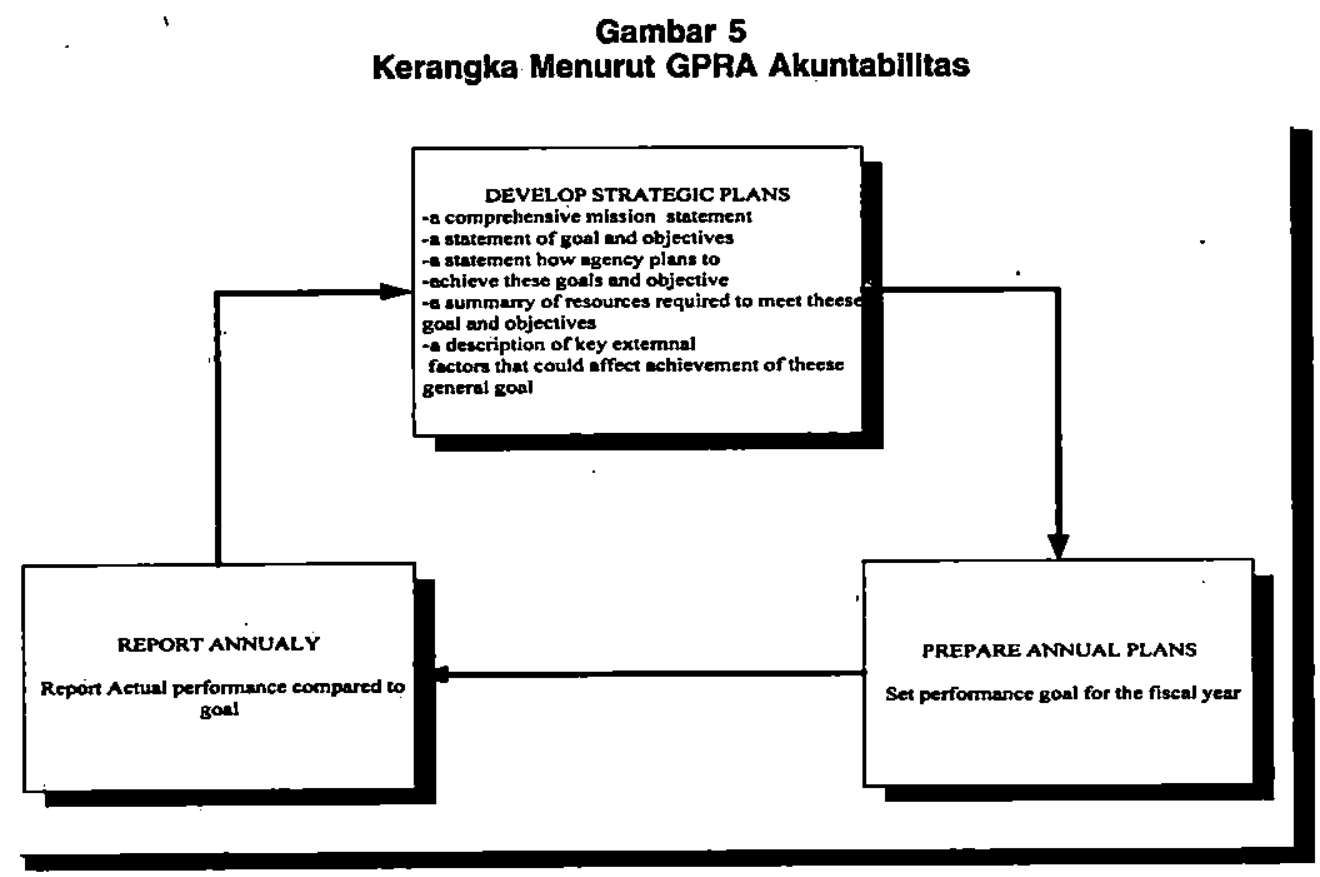


Topik: Sistem Pengukuran Kinerja Sektor Publik: Telaah Kritis Terhadap..., Mardiasmo

Berdasarkan dari kerangka kerja GPRA maka diturunkan kerangka kerja lain yakni kerangka kerja akuntabilitas DOE's yang kemudian dikenal sebagai DOE Strategic Management System (lihat Gambar 6).

\section{Gambar 6}

Kerangka Akuntabilitas Menurut Sistem Manajemen Strategl DOE

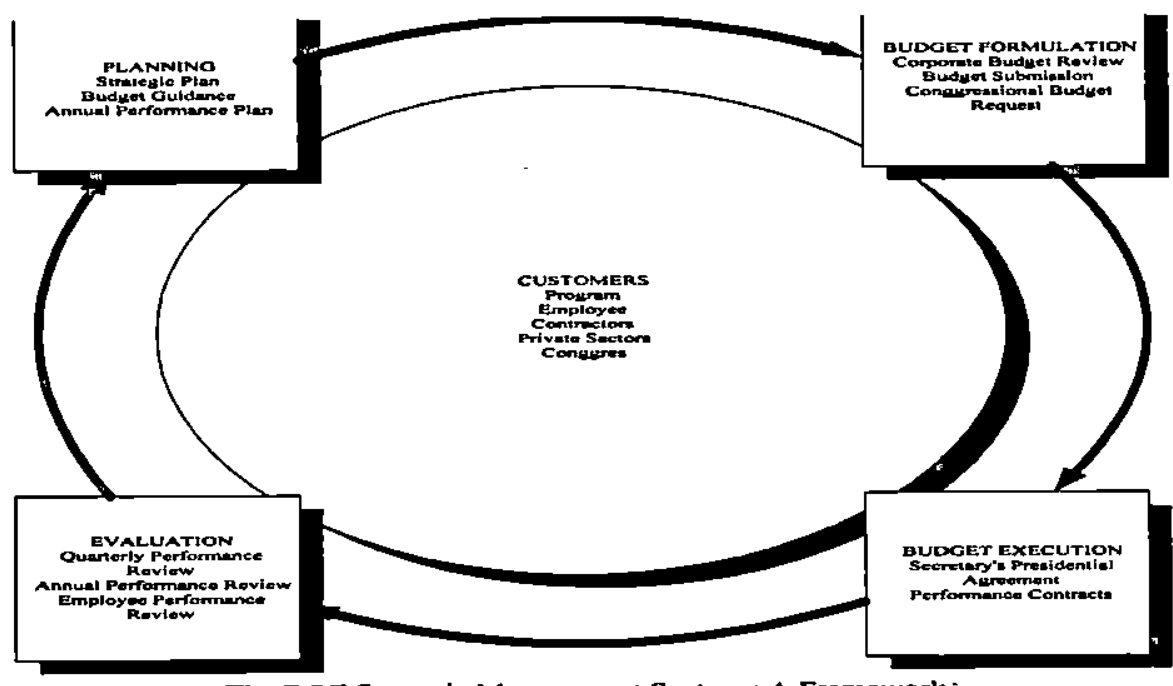

The DOE Strategic Maragement System : A Framework -

for Accountability

Sumber: Will Artley, Establishing Accountability for Performance, p. 18.

Sistem ini menunjukkan siklus akuntabilitas dan alat yang diperlukan untuk melengkapi siklus tersebut. Hal itu menarik untuk dicatat bahwa intinya, seluruh kerangka kerja proses manajemen berbasis kinerja merupakan siklus peningkatan berkelanjutan (Plan-Do-Check-Act Cycle). Hal ini merupakan suatu siklus yang sederhana.

\section{Alat-alat Akuntabilitas}

Akuntabilitas kinerja tidak dapat dibangun tanpa adanya atau tanpa menggunakan alat. Kenyataan ini merupakan keyakinan utama yang mendasari disusunnya Government Performance and Result Act 1993 (GPRA). Beberapa alat yang dapat dikemukakan disini belum dapat dikupas secara mendalam antara lain: 1. Rencana Strategik (Strategic Plans), 2.Rencana 
Kinerja (Performance Plans), 3. Kesepakatan mengenai Kinerja (Performance Agreement), 4. Laporan Akuntabilitas (ACcountability Report), 5.Kontrak Berbasis Kinerja (Performance Based Contract), 6.Selfassesment: Mutual Agreement, Reasonable Assurance, Continual Analysis, Demonstrating Performance Results, Reporting, 7.Review Kinerja dengan menggunakan metode Penilaian Kinerja 3600, 8. Pengendalian Manajemen, 9.Equity Statement, dan 10. Accountability Meetings.

\section{Penutup}

Perlunya penyusunan sistem pengukuran kinerja pada saat ini menjadi sesuatu yang urgen. Hal ini dipicu oleh kebutuhan internal maupun eksternal pemerintah daerah. Otonomi daerah dan desentralisasi fiskal telah memberikan keleluasaan (diskresi) pada daerah untuk mengembangkan sistem pengukuran kinerja sebagai bagian dari sistem pengelolaan keuangan daerah.

Pada masa yang akan datang kerangka kerja sistem pengukuran kinerja dapat saja menggunakan berbagai pendekatan yang sudah dikenal antara lain, Balance Scorecards, Public Sector Scorecards, $B a l d r i g e$ Awards dan lain sebagainya. Pemilihan tersebut tentunya harus memperhatikan karakteristik pemerintah daerah sebagai bagian dari sektor publik pada umumnya. Dengan adanya sistem pengukuran kinerja yang komprehensif dân terintegrasi maka diharapkan mampu meningkatkan akuntabilitas pemerintah daerah.

\section{Daftar Pustaka}

Abernethy M.A., et.al. 2001, "Decentralization, interdependence and Performance Measurement System Design: Sequences and Priorities", Center
Discusion Paper, NIVRA and The Austaliàn Research Council.

Alexander Kouzmin, Elke Loffler and Helmut Klages, and Nada Korac Kakabadse. 1999. "Bencmarking and Performance Measurement in Public Sector" The International Joumal of Public Sector Management, vol. 121 No.2, p. 121-144.

Andy N., et.al. 1995, "Performance Measurement System Design" International Journal of Operation and Production Management, vol. 15, p.80-116.

. 1999, "The Performance Measurement Revolution: Why Now and What Next? International Journal of Operation and Production Management, vol. 19, p.205-228.

Anthony R., D.B.A and David W. Y., D.B.A. 1994, Management Control in NonProfit Organization, fifth Edition.

Audit Commission UK, 1999. Performance Measurement as a Tool for Modemising Government; Using The PSAs to Drive Continuous Improvement, December 1999.

Auditor General of Alberta, 1997, Government Accountability, Available at: http://www.oag.ab.ca/html/ government_accountability.shtml.

Auditor General of British Columbia, 1996, Enhancing Accountability for Performance: A Framework and an Implementation Plan (Second Joint Report), Available at: $\leq \mathrm{http}: / /$ www.oag.bc.ca/PUBS/1995-96/> special/ account/ toc.htm.

BPKP, 2000, Tim studi Pengembangan Akuntabilitas Kinerja Instansi Pemerintah, Pengukuran Kinerja, 
Topik: Sistem Pengukuran Kinerja Sektor Publik: Telaah Kritis Terhadap..., Mardiasmo

Suatu Tinjauan Pada Instansi Pemerintah.

Brown, Mark Graham. 1999, "Baldrige Award Winning Quality: How to interpret the Maicom Baldrige Award Criteria." Ninth Edition, ASQ Quality Press.

Citizen's Circle for Accountability, 1996, Achieving Fairness Through Accountability, Available at: http: // www .magi .com/ hemccand/ cca.html.

1996, Background Documents, October, Available at: $\leq \mathrm{http}: / / \mathrm{www}$ magi .com/ hemccand $>$ /cca.html.

David Swindell. 2000, "Linking Citizen Satisfaction Data to Performance Measures" A preliminary Evaluation, Public Performance \& Management Review, Vol. 24, No.1, p.30-52.

Donnelly, M. 1998, "Making the Difference: Quality in The Public Sector", Proceedings of The 3rd International Conference on ISO 9000 and Total Quality Management, Ho, S.K.M. (ed.), p. 635-640, Hongkong Baptis University Press.

Epstein, P.D. 1988, "Using Performance measurement in local government: A guide to improving decisions, performance, and accountability", New York: National Civil League.

Frost and Bob. 1998, Measuring Performance, Fairway Press, Government of New South Wales, Government Record keeping Manual, "Records and Record keeping," 2000. A va ilableat:htt p:l/ www.records.nsw.gov.au/ publicsector/rk/rrk/rrk-09.htm.
Geertz B. 1993, "Measurement and Meaningful Management", Public Productivity and Management Review Vol. XVII No.1, Jossey-Bass Publisher.

Governmental Accounting Standard Board. 1999, Statement Concepts No. 34: Basic Financial Statement and Management's Discussion and Analysis-for State and Local Governments.

Greinner, J., et.all. 1981, Productivity and Motivation: A review of state and local government initiatives, Urban Institute Press, Washington D.C.http:// www .magi. com/ hemccand/resource.html.

James G. and Linda E. 1997, Performance Information and Program Evaluation in The Australian Public Sector" The International Journal of Public Sector Management, vol. 16. No. 3, p.154-164.

LAN. 2000," Akuntabilitas dan Good Governance." Lembaga Administrasi Negara.

Mardiasmo. 1999, "The Impact of Central and Provincial Governmental Intervention on Local Government Budgetary Management: The Case of Indonesia." Ph.D. Dissertation, The University of Birmingham.

, 2002, Otonomi Daerah dan Manajemen Keuangan Daerah, Penerbit Andi Yogyakarta.

Metcalfe, L., and Richards; S. 1987, "Improving Public Management." London: European Institute for Public Administration/Sage.

Office of the Auditor General Canada and Treasury Board Secretariat. 1998, Modernizing Accountability Prac- 
tices in the Public Sector, Available at: http://www.tbs-sct.gc.ca/rma/account/OAGTBS_E.html.

Peraturan Pemerintah (PP) No. 5 tahun 1975 tentang Pengurusan, Pertanggungjawaban dan Pengawasan Keuangan Daerah.

Peraturan Pemerintah (PP) No. 6 tahun 1975 tentang Cara Penyusunan Anggaran Pendapatan dan Belanja Daerah, Pelaksanaan Tatausaha Keuangan Daerah dan Penyusunan Perhitungan Anggaran Pendapatan dan Belanja Daerah.

Peraturan Pemerintah (PP) No. 105 tahun 2000 , tentang Pengelolaan dan Pertanggungjawaban Keuangan Daerah.

Peraturan Pemerintah (PP) No. 108 tahun 2000 , tentang Tatacara Pertanggungjawaban Kepala Daerah.

Shaw, A. 1999, A Guide to Performance Measurement and Non-Financial Indicators, The Foundation for Performance Measurement paper, c/o Metapraxis Ltd.

Streib G.D. and Theodore H. P. 1999, "Assesing the validity, legitimacy, and functionality of performance measurement system in municipal governments," American Review of Public Administration vol. 29. No 2.

Tuck N. and Gary Z. 1996, "Criteria for Developing Performance Measure- ment Systems: in The Public Sector", International Journal of Public Administration.

U. S. Department of Energy. 1996, Guidelines for Strategic Planning (DOE/ PO-0041), Available at: http:// www.osti.gov/policy/library/spguide.html.

Strategic Management System. Available at: http://www.osti.gov/ policy/sms/sms.html. (Note: This site contains copies of DOE's performance agreements, performance plans, accountability reports, strategic plans, and other pertinent information.)

Undang-undang (UU) No. 5 tahun 1974 tentang Pokok-pokok Pemerintah di Daerah.

Undang-undang (UU) No. 22 tahun 1999, tentang Pemerintahan Daerah.

Undang-undang (UU) No. 25 tahun 1999, tentang Perimbangan Keuangan antara Pemerintah Pusat dan Daerah.

Undang-undang (UU) No. 28 Tahun 1999 tentang Penyelenggaraan Negara yang Bersih dan Bebas dari Korupsi, Kolusi, dan Nepotisme.

Will A., and Suzane S. 2000, "Establishing an Integrated Performance Measurement System" Vol. 2, The Performance-Based Management Handbook. 